\title{
Development ideas changing the world
}

\section{Ideas de desarrollo cambiando el mundo}

Andres A. Chavez

Universidad Internacional del Ecuador, Ecuador

Autor para correspondencia: anchavezer@uide.edu.ec

Fecha de recepción: 25 de febrero de 2016 - Fecha de aceptación: 05 de abril de 2016

\section{Resumen}

A través de los siglos la gente ha tratado de encontrar formas de ayudar a los pobres del mundo a través de diferentes enfoques de desarrollo. En este trabajo se mostrará el enfoque de derechos humanos, el enfoque de capital humano, y el enfoque de las capacidades humanas.

Palabras claves: capital humano; capacidades humanas; derechos humanos; desarrollo

\begin{abstract}
Throughout centuries people have tried to find ways to help the poor people of the world through different development approaches. This paper will show the Human Rights Approach, The Human Capital Approach, and the Human Capabilities Approach.
\end{abstract}

Key words: human capital; human capabilities; human rights; development 


\section{Introducción}

After the great desolation brought about by World War I and World War II, the world changed in many ways. After these events, people tried to find ways to help the poor people of the world through different development approaches. However, not all these approaches have had the same impact in the lives of these people as the Human Development Approach. This paper will describe the Human Rights Approach and the Human Capital Approach, which are alternate ideas about development, as well as the Human Development Approach. The author will show the effect that the Human Development Approach has had in the world and how the birth of this approach was a turning point in the world of development.

\section{Human Rights Approach}

The main purpose of the right-based approach is to recognize that people possess intrinsic rights. Following the atrocities of World War II, there was a global movement whose focus was to ensure that "the individual human being be placed under the protection of the international community" (Tomuschat, 2012). As a result, the United Nations established many declarations in order to protect people, such as the Universal Declaration of Human Rights of 1948, the International Covenant on Civil and Political Rights of 1966, and the International Covenant on Economic, Social, and Cultural Rights of 1966. The initial declaration expressly states that "all human beings are born free and equal in dignity and rights" and have "the right to life, liberty and security of person" (The Universal Declaration, 1948). The subsequent covenants specify other rights such as the right of "self-determination" (International Covenant, 1966) and "the enjoyment of just and favorable conditions of work" (Tomuschat, 2012).

The main limitation of the Human Rights Approach is that these rights are not enforceable. They are meant to cover all people at an international level, but the local governments do not always support individuals in these rights. For example, according to דרדרthe Universal Declaration of Human Rights, all children should have the right to primary education, free of charge (The Universal Declaration, 1948). However, this is not the case in many countries of the world, and even when free education is provided, it is sometimes of such a poor quality that it does not serve the students or communities' needs. Additionally, even though the International Covenant on Economic, Social and Cultural Rights grants "the equal right of men and women to the enjoyment of all economic, social and cultural rights" (Tomuschat, 2012) there are still countries such as Saudi Arabia where women are legally required to ask permission to leave their homes (Gender Equality, 2012). A tragic example of unprotected rights is the demonstrators that were brutally killed in Egypt last year by the security forces of the government (Kirkpatrick, 2011). The fact that the UN says that individuals have certain rights does not mean that these rights will be protected for each individual around the world.

\section{Human Capital Approach}

The Washington Consensus, which was written in 1989 and consisted of policy reforms that the majority of Washington thought would be good for Latin America, is commonly considered the beginning of neoliberalism, also known as the human capital approach to development. This approach focuses on markets and "considers education relevant in so far as education creates skills and helps to acquire knowledge that serves as an investment in the productivity of the human being as an economic production factor, that is, as a worker" (Robeyns, 2006). Neoliberalism values economic increase above all other forms of development. 
Policies stemming from neoliberal approaches often treat people as commodities rather than human beings (Geo-JaJa \& Azaiki, 2010). This approach is insufficient because "it is economistic, fragmentized and exclusively instrumentalistic" (Robeyns, 2006). Human capital policies favor telling people what they need to do over empowering them to bring about changes in their own lives, and as a result have done little to actually help communities to develop. For example, in Nigeria, neoliberalism has led to a privatized education system that students cannot afford and that fails to prepare them to succeed in their communities (Geo-JaJa \& Azaiki, 2010). It is also due to these policies that many students receive classroom instruction in languages other than their mother tongue, which gives them little opportunity to truly learn and succeed. While a country's economic returns are vital to their development, the Human Capital Approach fails because it sacrifices the wellbeing of the people and their personal development in order to get the numbers to add up how they want them. Rather than strive to develop more capable humans, "it values education, skills and knowledge only in so far as they contribute (directly or indirectly) to expected economic productivity" (Robeyns, 2006).

\section{Human Capabilities Approach}

The Human Capabilities Approach was first introduced by Amartya Sen, a Nobel Prize winner in economics, in a lecture in 1979; after year of developing the idea, he fully explained this approach in his 1999 publication, Development as Freedom (Wells, 2012). This was the turning point that introduced a more effective and humanized way to bring about development in the world.

The focus of the Human Capabilities Approach is to enable individuals to lead lives they can value and have sufficient choices to make that life for themselves. Policies that arise from the Human Capabilities Approach can be evaluated across three concepts, which are their direct influence on people's wellbeing and freedom, the indirect role that they have in influencing economic production, and the way in which they shape social change (Sen, 1997). Sen cites Adam Smith in discussing the importance of nurturing a person's capabilities, using it to show how productive abilities lead to individual's abilities to lead various types of lives. Another important aspect of human capabilities is that economic prosperity is not the only factor that leads people to lead more enriching lives; "the scope of the capability approach, by contrast, is as wide as human life and social arrangements stretch in reality" (Robeyns, 2006). Other influences such as education and health care also have a great impact on the quality of life that people can choose to lead. Some of the social changes that can be brought about my improving human capabilities include reduced fertility in educated woman and improved quality of public debates among those who have completed a basic education.

\section{The effect of human capabilities in the world}

Programs inspired by the Human Capabilities Approach have had a great impact on the world. One example of such a program is one that was implemented by a non-government organization (NGO) called the Society for Integrated Development of Himalayas (SIDH). People from this NGO actually went to the area that they were striving to aid and thoroughly studied the conditions that were present there (Gupta, Joshi \& Crook, 2003). They hired local people to work for the NGO and trained them so that they would be able to teach their own people about the issues of gender sensitivity, health, and the reproductive process. They took the time to evaluate 
their project, and rather than blaming the people who received the aid for its failures, they adjusted their program so that they could better meet the needs of the local people and help them to help themselves. This is a great example of how aid should be administered. It should be given on a personal level according to the distinct needs and opportunities of each area.

Another program called the Six-Year Primary Project (SYPP) was carried out in South Western Nigeria (Geo-JaJa, 2009). This program was established to address the problem of African children being taught primarily in foreign languages, such as French, English, Portuguese, and Spanish (Babaci-Wilhite, Geo-JaJa \& Lou, 2012). The SYPP provided six years of primary education to an experimental group in the children's native tongue of Yoruba, and then compared these students' performance with that of their peers in a different class who had continued to receive instruction in English. The results "showed consistently that the experimental group performed highest on tests of all subjects including English" (Geo-JaJa, 2009). The developers of this project took the time to test their theory before mandating change, and were able to conclude that forcing a global language on children did not help them to succeed. This knowledge is vital to understanding how developers can help to empower the citizens of developing countries.

Communities that have been influenced by the Human Capabilities Approach are much more involved in important aspects of everyday life. In Switzerland, for example, the community has the opportunity to participate in important decision-making regarding education, such as building new schools, passing educational laws, and even choosing the teachers that will instruct their children (Mazurek, Winzer \& Majorek, 1999). This involvement allows everyone to have a voice and come together to do the best they can for their community.

\section{Conclusion}

There is still a lot of room for improvement in the way in which development is done in developing countries. Hundreds of millions of dollars are donated each year, but many of these countries still show minimal signs of progress. The Human Capabilities Approach has shown the world the changes that need to be made so that this money can truly make a difference and help these countries to reach their goals. This is a bottom up approach whose main focus is individuals, their needs, and the ways in which their capabilities can be enhanced. Through this approach, people are being empowered to become able to recognize and enforce their own human rights and not have to depend solely on international laws.

The Human Capabilities approach is one of the most significant turning points in the developing world. For hundreds of years' people believed that poverty had always been caused by a lack of money, which is the essence of the Human Capital Approach. However, the Human Capabilities Approach views poverty as the lack of health, education, community participation, and much more. Due to the emergence of this approach, there is hope that one day all individuals across the globe will be able to fully realize and enjoy their inherent human rights and potentials, and that donors will see people as more than workers but as human beings.

\section{Bibliography}


"Gender Equality in Saudi Arabia | Social Institutions and Gender Index (SIGI)." Social Institutions and Gender Index | OECD Development Centre. N.p., n.d. Web. 4 Dec. 2012. <http://genderindex.org/country/saudi-arabia\#_ftn71>.

Geo-JaJa; M. A. “Can globalization in Nigeria's Niger Delta be humanized for integration and development?" Language and Power The Implications of Language for Peace and Development. Eds. Brock-Utne, Birgit and Gunnar Garbo. Dares: Salaam. 2009. Print.

Geo-JaJa, M. A.\& Azaiki, S. "Development and education challenges in the Niger Delta”. Studies in African Education. Eds. Hui Xu, Lou, S. \& Xiu Lan Wan. Hangzhou: Zhejiang University Press. 2010. Print.

Gupta, P. Joshi, A, and Crook, B. “Gender and Social Justice: Society for Integrated

Development of the Himalayas (SIDH) Nurtures Young Men's Partnerships with Women". Three Case Studies: Involving Men to Address Gender Inequities. Washington, DC: International Gender Working Group. pp.31-51. 2003 Print.

"International Covenant on Economic, Social and Cultural Rights." United Nations. N.p., 16 Dec. 1966. Web. 4 Dec. 2012. <http://www2.ohchr.org/english/law/cescr.htm>.

Kirkpatrick, David. "Copts Denounce Egyptian Government Over Killings." The New York Times 11 Oct. 2011: A4. http://www.nytimes.com. Web. 3 Dec. 2012.

Mazurek, Kas, M. A. Winzer, and Czesław Majorek. "Changing Contexts and Evolving Prospects: Societal and Educational Dynamics in Switzerland." Education in a Global Society: A Comparative Perspective. Boston: Allyn and Bacon, 2000. Print.

Robeyns, Ingrid. "Three models of education Rights, capabilities and human capital." Theory and Research in Education 4.1 (2006): 69-84. Print.

Sen, Amartya. "Editorial: Human Capital and Human Capability." World Development 25.12 (1997): 1959-1961. Print.

"The Universal Declaration of Human Rights." The Universal Declaration of Human Rights. N.p., 10 Dec. 1948. Web. 3 Dec. 2012. <http://www.un.org/en/documents/udhr/history.shtml>.

Tomuschat, Christian. "International Covenant on Civil and Political Rights." United Nations. N.p., n.d. Web. 3 Dec. 2012. < http://untreaty.un.org/cod/avl/ha/iccpr/iccpr.html >.

Wells, Thomas. "Sen's Capability Approach." Internet Encyclopedia of Philosophy. N.p., 24 Apr. 2012. Web. 4 Dec. 2012. <http://www.iep.utm.edu/sen-cap/>.

Wilhite, Zehlia Babaci, Macleans A. Geo-JaJa, and Shizhou Lou. "Language and Curriculum as a Human Right for sustainable development in Africa." International Review of Education DOI: 10.1007/s11159-012-9311-7 (2012): 1-10. Print. 